\title{
Fiber Type Composition in Semitendinous Muscle of Wistar Rats and Effects of Intermittent Training on its Hypertrophy
}

\author{
Composición de los Tipos de Fibras del Músculo Semitendinoso de Ratas Wistar \\ y los Efectos del Entrenamiento Intermitente en su Hipertrofia
}

*Alexandre Ferreira \& * Gerson Eduardo Rocha Campos

\begin{abstract}
FERREIRA, A. \& CAMPOS, G. E. R. Fiber type composition in semitendinous muscle of wistar rats and effects of intermittent training on its hypertrophy. Int. J. Morphol., 26(1):63-67, 2008.

SUMMARY: Skeletal muscles respond to several stimuli changing their phenotype. Muscular fibers adaptation capability is related to the presence of several myosin heavy chains (MHC). These express four types of pure fibers: I, IIA, IID and IIB containing MHCI, IIa, IId and IIb, respectively. Among pure fibers, there are hybrid fibers, which can express two or more types of myosins. In this study, types of fibers constituting male Wistar rats semitendinous and their myosin heavy chains, as well as influence of intermittent training on hypertrophy of these fibers have been checked through MATPase histochemical technique and electrophoretic proteins separation. All types of pure and hybrid muscular fiber have been found, however the fibers of the types IIA, IID and IIB were predominant, featuring muscle as a fast-contracting one. Training has promoted muscular fibers transition with a significant increase of fibers of IC, IIAD and IIDB type. A cross-section increase of fibers of IIDB and IIB type has also been noticed. In summary, semitendinous muscle is essentially constituted by fast-contracting fibers and training could promote transition and hypertrophy of these fast fibers.
\end{abstract}

KEY WORDS: Semitendinous muscle; Muscle fibers; Intermittent training; Hypertrophy.

\section{INTRODUCTION}

The presence of different myosin heavy chains (MHC) allows skeletal muscles to adapt to several stimuli. These adaptations occur through gene changes that will express a new muscular fiber pattern, contributing this way to a heterogeneous phenotype (Demirel et al., 1999).

In adult rat skeletal muscles, there are four myosin heavy chains: MHCI, which will express slow-contracting of I type and, MHCIIa, MHCIId and MHCIIb, present in fastcontracting fibers of IIA, IID and IIB types, respectively (Campos et al., 2002). Hybrid fibers can be found among pure fibers, expressing two or more myosin types (Tajsharghi et al., 2004). This way, specific stimuli applied on muscles can provoke transition both from I to IIB (I=>IIA $=>$ IID $=>$ IIB) and from IIB to $\mathrm{I}(\mathrm{IIB}=>\mathrm{IID}=>\mathrm{IIA}=>\mathrm{I})$, always passing through hybrid ones, thus changing their phenotype.

Physical exercise is one of the specific factors affecting muscular fiber change (Andersen et al., 2000; Pette $\&$ Staron, 2001). For example, low-intensity and long- duration physical training may induce a conversion from fast to slow fibers. On the other hand, a high-intensity and shortduration training can lead to an opposite transition, that is, from slow to fast (Caiozzo et al., 2003).

The purpose of this study is to analyze fiber types constituting male Wistar rat semitendinous muscle and its myosin heavy chains, as well as to show these muscular fiber behavior when submitted to intermittent training.

\section{MATERIAL AND METHOD}

Animals. Sixteen Wistar breed and 21-day old male rats were used in the study. Two groups have been constituted with eight animals each, a control group (CG) and a trained group (TG). During the experimentation, animals were kept in a controlledtemperature environment $\left(18\right.$ to $22^{\circ} \mathrm{C}$ ), with a photoperiod of 12 hours and provided with food and water ad libitum.

\footnotetext{
* Sport's Institute - Faculdade Integradas Metropolitanas de Campinas - METROCAMP. Campus II, R. Madre Maria Santa Margarida, s/n - Nova Campinas, Campinas, São Paulo, Brasil.

*** Anatomy Department - Biology Institute, Universidade Estadual de Campinas - UNICAMP, Brasil.
} 
Training protocol. Animals have been trained on a motorized treadmill, during 6 days/weeks, for 8 weeks through intermitent training protocol (Table I) (Smolka et al., 2000). CG animals have not performed any kind of exercise.

Table I. Training protocol of the rats.

\begin{tabular}{lcccc}
\multicolumn{1}{c}{ Weeks } & $\mathbf{V}(\mathbf{m} / \mathbf{m i n})$ & $\mathbf{T}(\mathbf{m i n})$ & Interval (min) & Repeats \\
$1^{\text {st }}$ & 20 & 5 & 2 & 4 \\
$2^{\text {nd }}$ & 30 & 2.5 & 1 & 4 \\
$3^{\text {rd }}$ & 32.5 & 2.5 & 1 & 6 \\
$4^{\text {th }}$ & 35 & 2.5 & 1 & 6 \\
$5^{\text {th }}-8^{\text {th }}$ & 35 & 2.5 & 1 & 6
\end{tabular}

Sample preparation. After the training period, animals were sacrificed with an overdose of Ketamine and Kylasine Chloridrate (1:1). After this procedure, semitendinous muscle was removed and frozen in cooled isopentane in liquid nitrogen at $-176^{\circ} \mathrm{C}$ and stored in a freezer at $-80^{\circ} \mathrm{C}$. Then, $12 \mathrm{~mm}$ thick cross section were obtained from samples, in a cryostat, at $24^{\circ} \mathrm{C}$.

Histochemical and morphometric analysis. Sections have been submitted to mATPase (myofibrillar adenosine triphosphatase) reaction (Pette \& Staron) after pre-incubations in $\mathrm{pH}$ of 4.3, 4.5 (Brooke \& Kaiser, 1970) and 10.3 (Guth \&
Samaha, 1970), and fibers types were identified and counted. Cross-section area of about fifty fibers of each type (I-IIAIID-IIB) per animal was measured through Image ProExpress program.

Biochemical analysis. Sections of each sample have been collected for biochemical analysis. These were placed in $0.5 \mathrm{ml}$ of following medium: 10\% (w/v) glycerol, $5 \%(\mathrm{v} / \mathrm{v}) 2$ mercaptoethanol and $2.3 \%(\mathrm{w} / \mathrm{v})$ sodium dodecylsulfate (SDS), in $62.5 \mathrm{mM}$ Tris/HCL buffer (pH 6,8). Cuts were agitated during one minute and heated for 19 minutes, at $60^{\circ} \mathrm{C}$. Extract portions $(7 \mathrm{ml})$ were submitted to electrophoresis in gel (gradient of 7-10\%) of polyacrylamine (SDS), with 17-18 hours of running at $120 \mathrm{~V}$. After coloration with silver (Blum et al., 1987), gel was used to determine presence of MHC identified according to respective molecular masses. A soleum muscle sample was also included as control, as it presents in rats around 95\% of MHCI and 5\% of MHCII (Staron et al., 1999).

Statistical analysis. Results have been analyzed and expressed through their averages and standard deviation. Statistical significance of differences between averages of both groups was calculated through test t of Student and Mann Whitney for independent samples, through Instat program. Significance for $\mathrm{p}<0.05$ was considered significant.

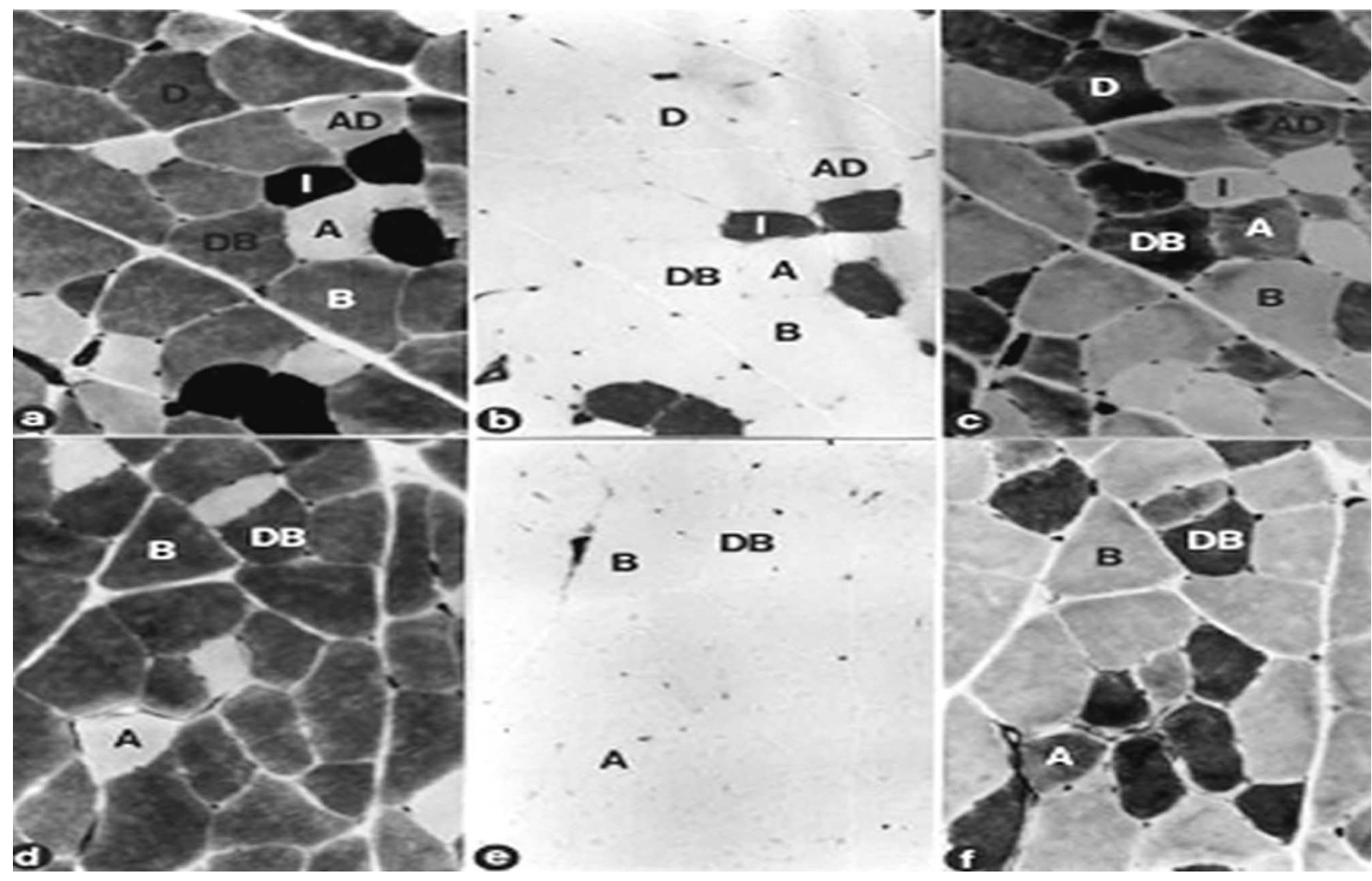

Fig. 1: mATPase histochemical reaction at $\mathrm{pH} 4.5(\mathrm{a}, \mathrm{d}), 4.3(\mathrm{~b}, \mathrm{e})$ and $10.3(\mathrm{c}, \mathrm{f})$ in serial cross sections of the semitendinous muscle of Wistar rats showed the fibers types. Red portion ( $a, b, c)$ and white portion (d, e, f). I-type I, IIC- type IIC, A- type IIA, AD- type IIAD, D- type IID, DB- type IIDB e B- type IIB. Authors' name: Ferreira, AD and Campos GER. 


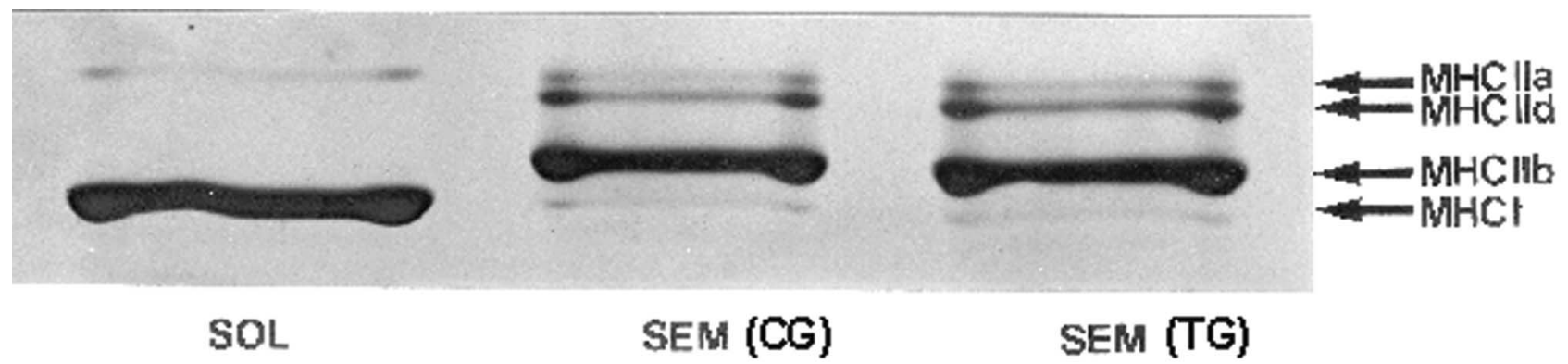

Fig. 2: Eletrophoretic separation of myosin heavy chain (MHC) isoforms from Wistar rat semitendinous muscles. This separation own MHC-IIa, MHC-IId, MHC-IIb and MHC-I. TG : Trained Group , CG : Control Group, SEM: semitendinous muscle and SOL: soleus muscle. Authors' name: Ferreira, AD and Campos GER.

\section{RESULTS}

Fibers types and Myosin heavy chains (MHC). All pure fiber types were present in this muscle (I, IIA, IID and IIB), as well as hybrid fibers IC, IIC, IIAD and IIDB (Fig. 1).

Through electrophoretic separation, presence of 4 myosin heavy chains (MHCI, IIa, IId and IIb) was evidenced in both groups. The IIb was predominant, the IIa and IId have showed a slight difference as to migration distance, and a similar proportion, while band I was slightly noticed (Fig. 2).

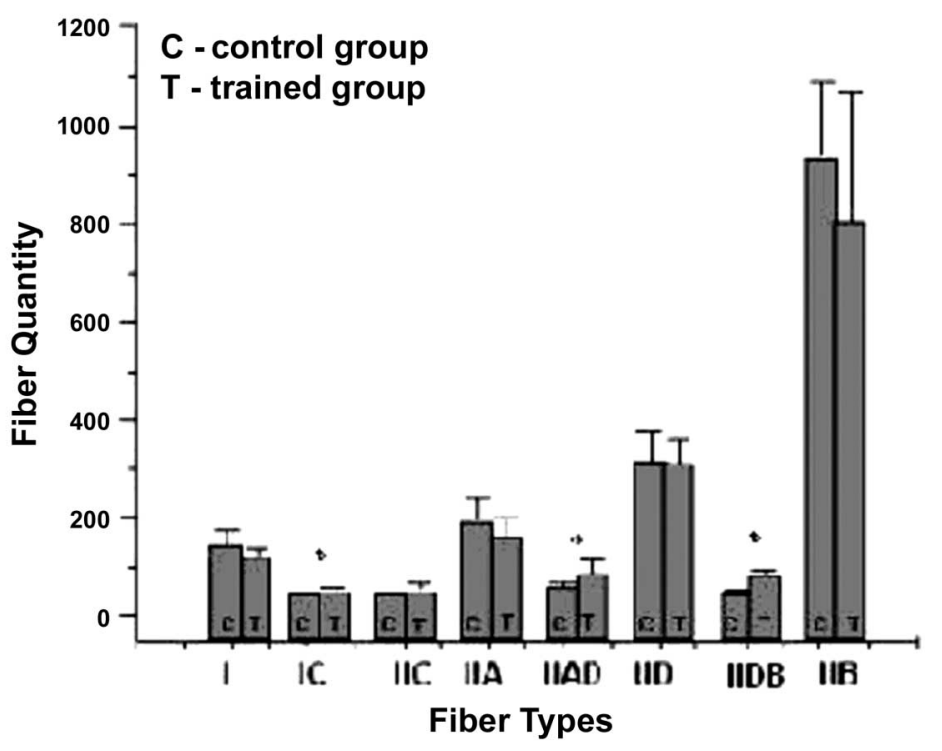

Fig. 3: Quantity of type fibers expressed in the whole semitendinous muscle (red portion plus white portion) of the control group and trained group. The fiber type IC, IIAD and IIDB showed increased statistical significant.

* Statistical significance.
Training effects. A significant increase on hybrid fibers of IC, IIAD and IIDB types could be noticed (Fig. 3) when was analyzed the all muscle. Cross-section area of red portion fibers of semitendinous muscle presented no change (Table II.B). On white portion, only IIB fibers showed a significant increase in their area (Table II.C) and, when both muscle portions were analyzed together, it was noticed that IIDB hybrid fibers suffered hypertrophy (Table II.A).

\section{DISCUSSION}

According to histochemical analysis of Wistar rat semitendinous muscle, all pure fibers were present, in which fast-contracting ones (IIA, IID and IIB) were the most expressive in the bouth groups, thus, semitendinous muscle can be rated as an essentially fast-contracting muscle. Some studies carried out with the same muscle, but from other animal species, showed results that corroborate this information (Delp \& Duan, 1996; Jurie et al., 1998). Electrophoretic separation of myosins in semitendinous muscle samples evidenced four bands: $\mathrm{IIb}$, found in larger quantity, followed by IId, IIa and I, respectively. This way, data confirm existence and proportion of IIB, IID, IIA and I fibers seen in optical microscopy (Figs.1 and 2).

Physical exercise is an important factor for muscular phenotype conversion. It can lead to a fiber bi-directional transition (Goldispink, 2003), depending on its periodicity, which can be set according to continuous charge principle (continuous training), mainly in long-duration activities, with higher volume and lower intensities. Or periodic charge one, whose directing principle is a lower duration and higher intensity, features that can be 
Table II. Comparison between the cross-sectional area of different fiber types of the simitendinous muscle of Wistar rats of both groups (TG and CG) with their means and standard deviation and also statistical significance. A. presents the cross-sectional area in the whole muscle carrying hypertrophy in the IIDB fibers. B. presents the cross-sectional area in the red portion, and don't have statistical significance in none fiber types. C. presents the cross-sectional area in the white portion carrying hypertrophy in the IIB fibers.

\section{A}

\begin{tabular}{|c|c|c|c|c|c|c|c|c|}
\hline & I & $\overline{\mathrm{IC}}$ & IIC & IIA & IIAD & IID & IIDB & IIB \\
\hline $\mathrm{TG}$ & $1337 \pm 222$ & $1397 \pm 160$ & $893 \pm 349$ & $1519 \pm 412$ & $1391 \pm 346$ & $1899 \pm 471$ & $2176 \pm 486 *$ & $3249 \pm 655$ \\
\hline $\mathrm{CG}$ & $1443 \pm 248$ & $1438 \pm 490$ & $1269 \pm 285$ & $1650 \pm 394$ & $1666 \pm 309$ & $1853 \pm 251$ & $1737 \pm 341 *$ & $2769 \pm 254$ \\
\hline \multicolumn{9}{|l|}{ B } \\
\hline $\mathrm{TG}$ & $1322 \pm 234$ & $1379 \pm 173$ & $893 \pm 349$ & $1511 \pm 424$ & $1393 \pm 364$ & $1927 \pm 497$ & $2059 \pm 479$ & $2832 \pm 616$ \\
\hline $\mathrm{CG}$ & $1443 \pm 252$ & $1438 \pm 490$ & $1269 \pm 285$ & $1660 \pm 408$ & $1685 \pm 432$ & $1929 \pm 380$ & $1647 \pm 474$ & $2626 \pm 441$ \\
\hline \multicolumn{9}{|l|}{ C } \\
\hline TG & ----------- & ------------ & ----------- & $1585 \pm 414$ & $1585 \pm 414$ & $1830 \pm 450$ & $2283 \pm 873$ & $3729 \pm 742 *$ \\
\hline $\mathrm{CG}$ & ----------- & ----------- & ----------- & $1582 \pm 369$ & $1611 \pm 288$ & $1736 \pm 290$ & $1923 \pm 246$ & $2876 \pm 222 *$ \\
\hline
\end{tabular}

worked out in intermittent training, in which physical exercise is performed in a discontinuous manner and is interrupted at regular intervals and then, applied again.

This way, protocol applied in this study is considered as intermittent (Smolka et al.) and induced muscular fibers changes. Therefore, observing the Fig. 3, an increase of IC, IIAD and IIDB hybrid fibers could be noticed, suggesting that training has induced MHC levels changes, through disturbances in genes expressing these proteins (Harrison et al., 2002), but was not able to fully convert them, maybe due to protocol application time or to and intensity that was not sufficiently high to promote full conversion. Nevertheless, fast-contracting fibers group presented the higher interference. So, that applied protocol recruits more fast-contracting fibers than slow-contracting ones. Training applied could not induce significant changes on red region muscular fibers size (Table IIB). On white region, there was a significant increase of fibers IIB area, and can be noticed on the whole muscle a hypertrophy of the IIDB (Table IIC and A), both representing fast-contracting group. According to previous studies, most recruited fibers in short-duration exercises are fast-contracting ones, indicating a high proteins production of some of these fibers, provoking their hypertrophy (Bottinelli \& Reggiani, 2000; Talmadge, 2000; Lin et. al., 2002).

In summary, it was demonstrated that semitendinous muscle is mainly constituted by fast-contracting fibers and that intervalled training could promote muscular fibers transition, with a significant increase of hybrid fibers IICIIAD- IIDB and a hypertrophy of fast-contracting fibers IIDB and IIB.

ACKNOWLEDGEMENTS. The CNPq - Brazil by the support to carry out this work. To the Anatomy and Biochemistry Departments of the Biology Institute UNICAMP, Brazil.

FERREIRA, A. \& CAMPOS, G. E. R. Composición de los tipos de fibras del músculo semitendinoso de ratas Wistar y las efectos del entrenamiento intermitente en su hipertrofia. Int. J. Morphol., 26(1):63-67, 2008.

RESUMEN: Los músculos esqueléticos responden a diversos estímulos cambiando su fenotipo. La capacidad de adaptación de las fibras musculares está relacionada con la presencia de diversas miosinas de cadena pesada (MHC). Estas miosinas expresan cuatro tipos de fibras puras: I, IIA, IID, IIB, que contienen MHCI IIa IId IIb, respectivamente. Entre las fibras puras hay fibras híbridas, las cuales pueden expresar dos o más tipos de miosinas. En este trabajo, se observaron los tipos de fibras y las cadenas pesadas de miosinas del músculo semitendinoso en ratas Wistar macho, así como también, la influencia del entrenamiento intermitente en la hipertrofia de aquellas fibras, a través de la técnica histoquímica de mATPasa y separación eletroforética de proteínas. Todos los tipos de fibras musculares puras e híbridas fueron encontradas, siendo las fibras de tipo IIA IID y IIB predominantes, por ser un músculo de contracción rápida. El entrenamiento promovió la transición de las fibras musculares con un aumento significativo de las fibras del tipo IC, IIAD y IIDB. En una sección transversal, un incremento de fibras del tipo IIDB y IIB también fue reportada. En resumen, el músculo semitendinoso está compuesto esencialmente por fibras de contracción rápida y el entrenamiento puede promover la transición e hipertrofia de las fibras musculares rápidas.

PALABRAS CLAVE: Músculo semitendinoso; Fibras musculares; Entrenamiento intermitente; Hipertrofia. 


\section{REFERENCES}

Andersen, J. L.; Schjerling, P. \& Saltin, B. Muscle, genes, and athletic performance. Sci. Am., 283:48-55, 2000.

Blum, H.; Beier, H. \& Gross, H. J. Improved silver staining of plant-proteins, RNA and DNA in polyacrylamide gels. Electrophoresis, 8(2):93-9, 1987.

Bottinelli, R. \& Reggianni, C. Human skeletal muscle fibres: molecular and functional diversity. Prog. Biophys. Mol. Bio., 73:195-262, 2000.

Brooke, M. H. \& Kaiser, K. K. Three "myosin adenosine triphosphatase" systems: the nature of their $\mathrm{pH}$ lability and sulfhydryl dependence. J. Histochem. Cytochem., 18:670-2, 1970.

Caiozzo, V. J.; Baker, M. J.; Huang, K.; Chou, H.; Wu, Y. Z. \& Baldwin, K. M. Single-fiber myosin heavy chain polymorphism: how many patterns and what proportions? Am. J. Physiol. Regul. Integr. Comp. Physiol., 285:R570-80, 2003.

Campos, G. E. R.; Luecke, T.; Wendeln, H. K.; Toma, K.; Hagerman, F. C.; Murray, T. F.; Ragg, K. E.; Ratames, N. A.; Kraemer, W. J. \& Staron, R. S. Muscular adaptationsin response to three different resistance training regimens: specificity of repetition maximum training zones. Eur. J. Appl. Physiol., 88:50-60, 2002.

Delp, M. D. \& Duan, C. Composition and size of type I, IIA, IID/X and IIB fibers and citrate synthase activity of rat muscle. J. Appl. Physiol., 80:261-70, 1996.

Demirel, H. A.; Powers, S. K.; Naito H.; Hughes M. \& Coombes, J. S. Exercise-induced alterations in skeletal muscle myosin heavy chain phenotype: dose-response relationship. J. Appl. Physiol., 86(3):1002-8, 1999.

Goldispink, G. Gene expression in muscle in response to exercise. J. Muscle Res. Cell, 24:121-6, 2003.

Guth, L. \& Samaha, F. J. Procedure for the histochemical demonstration of actomyosin ATPase. Exp. Neurol., 28:365-7, 1970.

Harrison, B. C.; Bell, M. L.; Allen, D. L.; Byrnes, W.C. \& Leinwand, L. A. Skeletal muscle adaptations in response to voluntary wheel running in myosin heavy chain null mice. J. Appl. Physiol. 92:313-22, 2002.
Jurie, C.; Picard, B. \& Geay, Y. Influences of the method of housing bulls on their body composition and muscle fibre types. Meat Science, 50:457-69, 1998.

Lin, J.; Wu, H.; Tarr, P. T.; Zhang, C. Y.; Wu, Z.; Boss, O.; Michael, L. F.; Puigserver, P.; Isotani, E.; Olson, E. N.; Lowell, B. B.; Bassel-Dub,Y. R. \& Spiegelman, B. Transcriptional co-activator PGC-1a drives the formation of slow-twich muscle fibres. Nature, 418:797-801, 2002.

Pette, D. \& Staron, R. S. Transitions of muscle fiber phenotypic profiles. Histochem. Cell Biol., 115:359-72, 2001.

Smolka, M.B.; Zoppi, C. C.; Alvez, A.A.; Silveira, L.R.; Marangoni, S.; Silva, L. P.; Novello, J. \& Macedo, D. V. HSP72 as a complymentary protection against oxidative stress induced by exercise in the soleus muscle of rats. Am. J. Physiol. Regulatory Integrative Comp. Physiol., 279:R1539-45, 2000.

Staron, R. S.; Kraemer, W. J.; Hikida, R. S.; Fry, A. C.; Murray, J. D. \& Campos, G. E. R. Fiber type composition of four hindlimb muscles of adult Fisher 344 rats. Histochem. Cell Biol., 111:117-23, 1999.

Tajsharghi, H.; Sunnerhagen, K. S.; Darin, N.; Kyllerman M. \& Oldfors, A. Induced shift in myosin heavy chain expression in myosin myopathy by endurance training. J. Neurol., 251:179-83, 2004.

Talmadge, R. J. Myosin heavy chain isoform expression following reduced neuromuscular activity: potential regulatory mechanisms. Muscle Nerve, 23:661-79, 2000.

Correspondence to:

Alexandre Ferreira

Rua Padre Vieira, № 654, Ap. 94, Centro.

CEP: 13015-301

Campinas, São Paulo

BRAZIL.

E-mail: alefef@gmail.com

Received: 03-10-2007

Accepted: 22-11-2007 
